A N N A L E S

UNIVER S T A T IS MARIAE CURIE-SKŁODOW S A LUBLIN - POLONIA

VOL. XXIX, 1

SECTIO J

2016

Uniwersytet Kardynała Stefana Wyszyńskiego w Warszawie. Wydział Prawa i Administracji

\title{
ANNA MARIA SZLUZ
}

a.szluz@gmail.com

\section{Umocowania prawne \\ polskich uniwersytetów trzeciego wieku}

Legal Powers Polish Universities of the Third Age

\section{STRESZCZENIE}

Głównym celem artykułu jest zobrazowanie modelu polskich uniwersytetów trzeciego wieku. Opracowanie ukazuje najważniejsze zmiany organizacyjne tych podmiotów, uwarunkowane przez czynniki wewnętrzne i zewnętrzne. Wywód przybliża czynniki różnicujące oraz charakterystykę uniwersytetów dla osób starszych.

Slowa kluczowe: prawo; uniwersytety trzeciego wieku; srebrna ekonomia; kreatywna polityka senioralna; kształcenie ustawiczne

\section{WPROWADZENIE}

Podstawą realizacji idei budowania społeczeństwa opartego na wiedzy jest nadanie rangi koncepcji uczenia się przez całe życie (Lifelong Learning ${ }^{1}$ ). W polskich realiach istotną rolę odgrywają w tym zakresie uniwersytety trzeciego wieku (UTW), których funkcjonowanie wymaga współpracy wielu podmiotów: administracji rządowej i samorządowej, instytucji naukowych i oświatowych oraz

${ }^{1}$ The Lifelong Learning Programme (LLP) jest inicjatywą Unii Europejskiej. Jego celem jest rozwój różnych form uczenia się przez całe życie poprzez wspieranie współpracy między systemami edukacji i szkoleń w krajach uczestniczących. Program ma się przyczynić do podnoszenia jakości i zwiększenia atrakcyjności szkolnictwa oraz kształcenia zawodowego w Europie. 
organizacji pozarządowych. Działalność UTW - osadzona na określonych podstawach prawnych - aktywizuje osoby starsze i ma wpływ na procesy społeczno-ekonomiczne (silver economy oznacza dział gospodarki skupiony na zaspokojeniu potrzeb wynikających ze starzenia się ludności), w których te jednostki uczestniczą. Prawne i organizacyjne formy funkcjonowania UTW są zróżnicowane i nie podlegają jednolitym unormowaniom. Celem artykułu jest zobrazowanie umocowań prawnych polskich uniwersytetów trzeciego wieku.

\section{SPECYFIKA UNIWERSYTETÓW TRZECIEGO WIEKU}

Początki UTW sięgają 1972 r., w którym Pierre Vellas, profesor Uniwersytetu w Tuluzie, zorganizował spotkanie seniorów mające na celu poznanie odpowiedzi na pytanie, czego oczekują oni od uniwersytetu. Wówczas sformułowano trzy postulaty (podstawy tzw. modelu francuskiego): 1) potencjał medyczny uniwersytetu powinien służyć propagowaniu wiedzy na temat utrzymania zdrowia w wieku starczym, 2) upowszechniana wiedza o kulturze powinna być wzbogacona o doświadczenie i wiedzę ludzi starszych, 3) potencjał badawczy powinien zostać zmobilizowany dla rozwiązywania problemów ludzi starszych oraz starości (Zan 1993, s. 350; Konieczna-Woźniak 2001, s. 40-43). Pierwsza placówka powstała we Francji w 1973 r., a w kolejnych latach podobne podmioty zorganizowano we Francji i w innych krajach. W następnych latach francuskie UTW przekształciły się w placówki otwarte na wszystkie grupy wiekowe.

Pierwszy UTW w Polsce powstał w Warszawie w 1975 r. z inicjatywy Haliny Szwarc². Do celów pierwszego UTW zaliczono włączenie osób starszych do systemu kształcenia ustawicznego, ich aktywizację intelektualną, psychiczną oraz fizyczną, opracowanie metod edukacji i wdrożenie profilaktyki gerontologicznej, a także prowadzenie obserwacji i badań naukowych (Informator... 1987). Początkowo uniwersytety funkcjonowały w strukturach wyższych uczelni, przede wszystkim w dużych miastach. W kolejnych latach wzrastała liczba UTW (rys. 1), co można uzasadniać zwiększającą się liczbą osób starszych (procesem starzenia się społeczeństwa).

Z badania przeprowadzonego przez Główny Urząd Statystyczny (GUS) wynika, że najwięcej z funkcjonujących UTW (44\%) powstało w latach 2006-2010. Po stałym wzroście liczby uniwersytetów w tym okresie, w kolejnych latach ten-

${ }^{2}$ Z inicjatywy profesor H. Szwarc w 1975 r. przy Centrum Medycznym Kształcenia Podyplomowego w Warszawie powstał UTW będący pierwszą taką placówką w Polsce i jedną z pierwszych w Europie. Obecnie podmiot nosi imię założycielki, która w następnych latach była inicjatorką powołania w Polsce kolejnych tego typu uniwersytetów: w 1976 r. we Wrocławiu, w 1977 r. w Opolu, w 1978 r. w Szczecinie, a następnie w Łodzi i kilku innych większych miastach. W 1980 r. H. Szwarc wystąpiła z inicjatywą powołania UTW w Lublinie. Pomysł trafił do Zarządu Lubelskiego Oddziału Towarzystwa Wolnej Wszechnicy Polskiej, w którym działali pracownicy Zakładu Andragogiki Uniwersytetu Marii Curie-Skłodowskiej w Lublinie (Uniwersytety Trzeciego Wieku). 


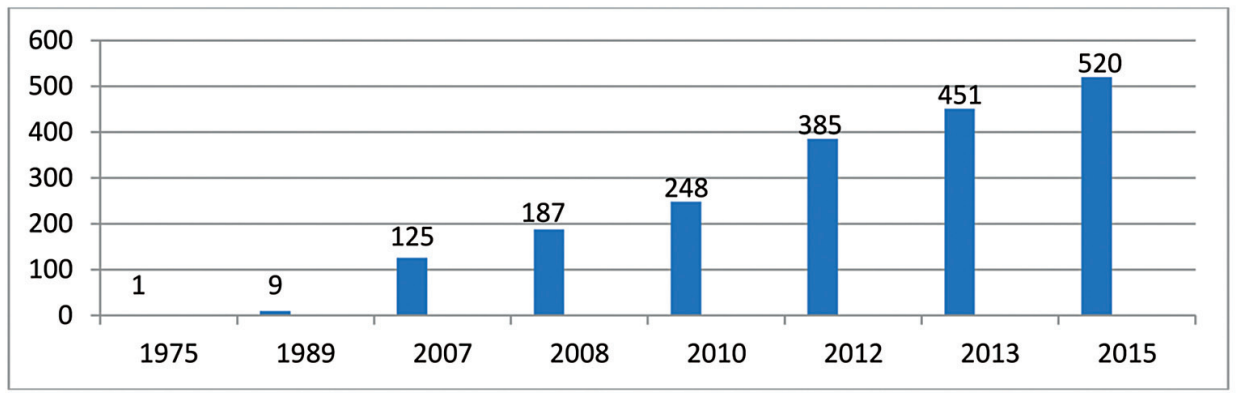

Rys. 1. Liczba UTW w Polsce w latach 1975-2015

Źródło: Uniwersytety trzeciego wieku... 2013, s. 1; Borczyk 2015.

dencja ta uległa zahamowaniu. Od 2011 do 2015 r. utworzono tylko 145 nowych podmiotów. Z danych przedstawionych przez UTW wynika, że w roku akademickim 2014/2015 z oferty edukacyjnej skorzystało 96370 seniorów, co stanowiło $95,7 \%$ osób, które wyraziły chęć uczestnictwa w zajęciach. Ponad 2 tys. osób nie mogło z nich skorzystać ze względu na brak miejsc. Najlepszym wynikiem aktywizowania osób starszych wykazało się województwo lubuskie, w którym na 10 tys. mieszkańców w wieku powyżej 50. roku życia ponad 113 osób uczestniczyło w zajęciach UTW. Najmniej uczestników, bo tylko 28,5 na 10 tys. mieszkańców, było w województwie świętokrzyskim (w Polsce 69,06 na 10 tys. mieszkańców). Dominowały kobiety - ich odsetek wynosił $86 \%$ członków UTW. 59,7\% uczestników stanowiły osoby w wieku od 60 do 70 lat. 34,4\% ogółu kobiet UTW reprezentowały osoby w wieku od 60 do 65 lat, natomiast $28,6 \%$ ogółu mężczyzn UTW było w wieku od 66 do 70 lat. 49\% członków posiadało wykształcenie średnie, 39\% stanowiły osoby z wykształceniem wyższym, 8\% - zawodowym, a 4\% - podstawowym.

Uniwersytety finansowały swoją działalność z różnych źródeł. Najwięcej z nich $(77,6 \%)$ było finansowanych przynajmniej w części z opłat wnoszonych przez słuchaczy. 64,9\% uczelni korzystało z dotacji ze środków samorządowych, a 53,4\% - ze składek członkowskich. Z kolei respondenci wskazywali następujące źródła finansowania: 35\% - opłaty uczestników (wpisowe, czesne za zajęcia), $18 \%$ - składki członkowskie, $25 \%$ - dotacje samorządowe (miasta, gminy, powiatu, województwa), 8\% - źródła publiczne (rządowe, np. środki ministerstw, wojewodów, Funduszu Inicjatyw Obywatelskich [FIO], Rządowego Programu na rzecz Aktywności Społecznej Osób Starszych [ASOS], środki od instytucji i organizacji, w ramach których działa UTW), 3\% to inne źródła. 49,2\% UTW wskazało jako barierę w funkcjonowaniu niewystarczające środki finansowe. Innymi trudnościami, na które napotykały podmioty, były: zbyt niskie dochody słuchaczy utrudniające wnoszenie opłat (39,9\%), zbyt mała liczba wolontariuszy gotowych 
pracować na rzecz UTW (27,8\%), braki w wyposażeniu (24,1\%), a także utrudniony dostęp do pomieszczeń (19,8\%). Brak trudności w funkcjonowaniu zadeklarowało 22,8\% uniwersytetów (GUS 2015, s. 1-7) $)^{3}$.

Klasyczny model funkcjonowania UTW zakłada, że jest to instytucja uniwersytecka o charakterze gerontologicznym, której głównym celem jest prowadzenie badań naukowych skoncentrowanych na problematyce starości i procesie starzenia się, ukierunkowanych na optymalizację życia seniorów i poprawę jakości życia oraz wspieranie rozwoju (Czerniawska 2007, s. 216; Szluz 2009, s. 163-171). Wyodrębniono także modele podziału UTW ze względu na kryterium siły związku z uczelniami wyższymi - jest to model francuski i brytyjski. W pierwszym UTW są związane z ośrodkami akademickimi, w związku z czym cechuje je wysoki poziom działalności dydaktycznej i naukowej. Są one zróżnicowane pod względem form organizacyjnych: od pełnej integracji z uczelnią, przez współpracę, do niezależności od uczelni. Odmienny jest model brytyjski opracowany przez P. Laslett (Ziębińska 2007, s. 156-164), który jest oparty na samokształceniu i samopomocy seniorów, lecz bez wsparcia ze strony uczelni.

W ostatnich latach pojawiły się nowe modele UTW - krajowe i kontynentalne, m.in. w Stanach Zjednoczonych, Kanadzie, Rosji, Chinach, a także w Ameryce Południowej (Schwarz, Lentzy, Hipp 2008, s. 481-494; Batorski, Zając [red.] 2010; Kresl, Daniele 2010; Klimczuk 2011, s. 57-75; Klimczuk 2012, s. 52-56; Marcinkiewicz 2012, s. 459-460; Klimczuk 2013, s. 8). Przyjęto nowe cele, które obejmują: zarządzanie czasem wolnym seniorów i kompensowanie spadku liczby studentów w szkolnictwie wyższym; przeciwdziałanie wykluczeniu cyfrowemu seniorów; wpływ na rozwój miast i regionów; kształtowanie podstaw silver economy; ukierunkowanie na dostosowanie sfery produkcji oraz dystrybucji towarów i usług do potrzeb starzejącej się populacji.

\section{FORMY ORGANIZACYJNO-PRAWNE UNIWERSYTETU TRZECIEGO WIEKU}

UTW działają w różnych formach organizacyjno-prawnych jako: podmioty działające w strukturach wyższych uczelni, samodzielne organizacje pozarządowe, jednostki organizacyjne wyodrębnione w ramach innej organizacji pozarządowej, a także podmioty prowadzące działalność w strukturach jednostek organizacyjnych samorządu terytorialnego (lokalnego).

Ustawa z dnia 27 lipca 2005 r. - Prawo o szkolnictwie wyższym dotychczas nie definiuje zakresu działania uczelni, z którego wynikałoby jednoznacznie uprawnienie do prowadzenia kształcenia nieformalnego osób starszych. Wśród podstawowych zadań uczelni wymieniono działanie na rzecz społeczności lokalnych i regionalnych (art. 13 ust. 1.8). Brak podstawy prawnej jest poważnym pro-

${ }^{3}$ Kolejne badanie UTW jest przewidziane na IV kwartał 2018 r., z danymi za rok akademicki 2017/18. 
blemem, biorąc pod uwagę fakt, iż coraz większa liczba osób starszych jest zainteresowana członkostwem w UTW. W związku z tym pojawia się wątpliwość, czy uczelnie wyższe mogą przeznaczać środki finansowe na działalność ukierunkowaną na kształcenie osób starszych. Uniwersytety trzeciego wieku, działające $\mathrm{w}$ ramach wyższych uczelni w Polsce, są powoływane przez władze uczelni i kierowane przez pełnomocnika rektora. Tworzenie UTW nie jest formalnie obowiązkiem uczelni czy, szerzej mówiąc, państwa. Podmioty te są strukturalnie i finansowo uzależnione od władz uczelni, która ustala zasady ich działania. Utrzymanie UTW może stanowić dla uczelni obciążenie finansowe, np. wykorzystywane są sale na wykłady, za które uczelnia nie pobiera opłat, uczestnicy korzystają ze środków dydaktycznych niezbędnych podczas zajęć. Uczelnia partycypuje zatem w organizowaniu i prowadzeniu zajęć, za które słuchacze wnoszą opłaty (np. miesięczne czesne).

UTW mogą funkcjonować jako organizacje pozarządowe. Najczęściej są to stowarzyszenia ${ }^{4}$, działają zatem w oparciu o ustawę - Prawo o stowarzyszeniach oraz ustawę o działalności pożytku publicznego i wolontariacie. UTW mogą także działać jako fundacje w oparciu o ustawę z dnia 6 kwietnia 1984 r. o fundacjach. W świetle pierwszej z ustaw stowarzyszenie jest dobrowolnym, samorządnym, trwałym zrzeszeniem o celach niezarobkowych. Samodzielnie określa swoje cele oraz programy działania i struktury organizacyjne, uchwala też akty wewnętrzne dotyczące prowadzonej działalności (art. 2.1 i 2). Osoby w liczbie co najmniej siedmiu (do 20 maja 2016 r. - co najmniej 15), które zamierzają założyć stowarzyszenie, uchwalają statut stowarzyszenia i wybierają komitet założycielski albo władze (art. 9). Wspomniany statut określa nazwę stowarzyszenia, odróżniającą je od innych podmiotów, organizacji i instytucji, a także teren działania i siedzibę. Wskazuje również cele i sposoby ich realizacji, sposób nabywania i utraty członkostwa, przyczyny jego utraty oraz prawa i obowiązki członków. W statucie zawiera się zapis dotyczący władz stowarzyszenia, trybu dokonywania ich wyboru, uzupełniania składu oraz ich kompetencji. Od 20 maja 2016 r. uwzględniono ponadto możliwość otrzymywania przez członków zarządu wynagrodzenia za czynności wykonywane $\mathrm{w}$ związku $\mathrm{z}$ pełnioną funkcją. W dokumencie określa się sposób reprezentowania stowarzyszenia, w szczególności sposób zaciągania zobowiązań majątkowych, oraz warunki ważności uchwał władz stowarzyszenia, sposób uzyskiwania środków finansowych i ustanawiania składek członkowskich. Zapisuje się ponadto zasady dokonywania zmian statutu i sposób rozwiązania stowarzyszenia (art. 10.1-9). UTW są zatem niezależne w działaniu, posiadają władze (zarząd i organ kontroli wewnętrznej), które są wybierane zgodnie z procedurami ustalonymi w statutach. Członkowie opłacają składki członkowskie lub

${ }^{4} \mathrm{Z}$ przeprowadzonych badań wynika, że najpowszechniejszą z form funkcjonowania UTW jest samodzielnie działające stowarzyszenie (Ogólnopolska Federacja Stowarzyszeń Uniwersytetów Trzeciego Wieku 2012, s. 12). 
wnoszą opłaty za zajęcia. Podmioty te często współpracują z innymi organizacjami pozarządowymi, jednostkami samorządu terytorialnego oraz uczelniami wyższymi. Uczelnie wyższe obejmują UTW patronatem i współdziałają w zakresie obsady kadrowej prowadzonych zajęć. Część UTW funkcjonuje jako jednostki organizacyjne w strukturach różnego rodzaju stowarzyszeń i fundacji. Podstawę stanowią przyjęte cele statutowe, które są związane również z działalnością na rzecz osób starszych. Tego typu podmioty działają w oparciu o statut danej organizacji pozarządowej, powołują jednak swój zarząd oraz inne organy.

Podstawowym źródłem finansowania jest składka członkowska i działalność statutowa. Samorządy lokalne mają obowiązek opracowania i ogłoszenia programu współpracy z organizacjami pozarządowymi, ponieważ formy wsparcia są przewidziane w ustawie z dnia 24 kwietnia 2003 r. o działalności pożytku publicznego i o wolontariacie (art. 5a). Niektóre UTW składają zatem wnioski o dofinansowanie do jednostki samorządu terytorialnego bądź o wsparcie w formie rzeczowej (takie jak np. baza lokalowa, wyposażenie biurowe, pomoc organizacyjna itp.).

Uniwersytety działają także w strukturach jednostek organizacyjnych samorządu lokalnego (np. centrach kultury, centrach kształcenia ustawicznego, bibliotekach, ośrodkach pomocy społecznej itp.). UTW działające w strukturach samorządowych są powoływane przez władze samorządowe i kierowane przez wyznaczonych pracowników. Władze samorządowe określają zasady ich działania i wspierają w organizowaniu zajęć. Uczestnicy wnoszą opłaty za zajęcia. UTW nie posiadają zatem samodzielności i odrębności w działaniu, są strukturalnie i finansowo zależne od jednostek organizacyjnych samorządów.

Uniwersytety (niezależnie od tego, w jakiej formie organizacyjno-prawnej funkcjonują) nie mają trwałego finansowania, dlatego z inicjatywy Polsko-Amerykańskiej Fundacji Wolności ${ }^{5}$ przez konkurs grantowy umożliwiono UTW dofinansowanie do wydatków związanych z prowadzeniem działalności. Od 2005 r. rozpoczęto realizację programu mającego na celu promowanie wśród osób starszych działań edukacyjnych i aktywizujących, a także społecznego zaangażowania oraz działań międzypokoleniowych. Przedsięwzięcie jest realizowane przez wsparcie i promocję inicjatyw społecznych, wykorzystanie potencjału, wiedzy, doświadczenia seniorów w działaniach na rzecz własnego otoczenia oraz przez wsparcie UTW. Wyznaczono kryteria ubiegania się przez uniwersytety o udział

${ }^{5}$ W ramach konkursu „Seniorzy w Akcji” są oferowane granty i szkolenia dla osób powyżej 60. roku życia, które - samodzielnie lub we współpracy z osobą młodą - chcą realizować działania społeczne i międzypokoleniowe oparte na własnym pomyśle. Adresatami konkursu są aktywni seniorzy działający zarówno w ramach UTW, jak i we współpracy z innymi organizacjami pozarządowymi i instytucjami. Dotychczas (dane z 2016 r.) zostały dofinansowane 264 projekty międzypokoleniowe, mobilizujące osoby starsze do działania na rzecz ich otoczenia oraz promujące wolontariat seniorów (Polsko-Amerykańska Fundacja Wolności). 
w konkursie grantowym. Są to: powołanie zarządu, w skład którego powinni wejść pracownicy naukowi, a także samorządu oraz rady programowej, którą mają tworzyć osoby ze statusem naukowym; określenie przez UTW kryteriów w zakresie naboru uczestników; opracowanie programu działania na co najmniej jeden semestr akademicki oraz planu i tematyki zajęć, pozyskanie wykładowców; określenie struktury UTW, działań w grupach, zajęć w formie wykładów i konwersatoriów oraz typu studyjnego; opracowanie statutu lub regulaminu; podpisanie umowy współpracy z instytucją naukową obejmującą UTW patronatem naukowym, współpracą i nadzorem.

\section{ZAKOŃCZENIE}

Działania edukacyjne są jednym z ważniejszych elementów poprawy jakości życia osób starszych. Aktywność edukacyjna charakteryzuje tylko niewielką część polskich seniorów, najczęściej tych, którzy posiadają co najmniej średnie wykształcenie (Halicki 2009, s. 208). Wyodrębniono dwa główne etapy w zakresie edukacji osób starszych. Pierwszy - do końca lat 60. XX w., w którym postrzegano kształcenie seniorów w kontekście form prowadzonej polityki społecznej. Zwolennikiem takiego pojmowania edukacji był R. Moody. Z kolei w latach 70. H.Y. McClusky (1971) stworzył koncepcję edukacji do starości ze zwróceniem uwagi na hierarchię potrzeb osób starszych. Na różnych płaszczyznach potrzeb wskazał na wzajemne stosunki między zewnętrznymi wymaganiami i osobistymi zasobami (Halicki 2000, s. 51). Współcześnie bierze się również pod uwagę działania edukacyjne skierowane do osób w najpóźniejszym okresie starości, tzn. powyżej 80. roku życia („czwarta generacja”). Pojawił się postulat utworzenia uniwersytetu czwartego wieku (umożliwiającego udział z zastosowaniem Internetu). Potrzeby i problemy seniorów stają się zatem impulsem do badań naukowych oraz działań na rzecz seniorów. W tym kontekście umocowania prawne UTW są podstawą funkcjonowania prezentowanych podmiotów.

\section{BIBLIOGRAFIA}

Batorski D., Zając J.M. (red.) (2010), Między alienacja a adaptacją. Polacy w wieku 50+ wobec Internetu, Warszawa: UPC Polska, ARFP.

Borczyk W. (2015), W Polsce działa 520 Uniwersytetów Trzeciego Wieku, www.polskieradio.pl/7/129/Artykul/1410188, Wieslawa-Borczyk-w-Polsce-dziala-520-UniwersytetowTrzeciego-Wieku (dostęp: 12.02.2016).

Czerniawska O. (2007), Szkice z andragogiki i gerontologii, Łódź: Wydawnictwo Wyższej Szkoły Humanistyczno-Ekonomicznej.

GUS (2015), Uniwersytety Trzeciego Wieku - wstępne wyniki badania, Gdańsk: Departament Badań Społecznych i Warunków Życia GUS, Urząd Statystyczny w Gdańsku. 
Halicki J. (2000), Edukacja seniorów w aspekcie teorii kompetencyjnej. Studium historyczno-porównawcze, Białystok: Wydawnictwo Uniwersyteckie.

Halicki J. (2009), Edukacja w starości jako działanie poprawiajace jakość życia seniorów, „Chowanna", 2.

Informator Sekcji UTW przy Polskim Towarzystwie Gerontologicznym, 1987.

Klimczuk A. (2011), Transfer technologii w ksztattowaniu srebrnej gospodarki, [w:] M. Grzybowski (red.), Transfer wiedzy w ekonomii i zarzadzaniu, Gdynia: Wydawnictwo Uczelniane Akademii Morskiej.

Klimczuk A. (2012), Supporting the Development of Gerontechnology as Part of Silver Economy Building, "Ad Alta: Journal of Interdisciplinary Research", 2.

Klimczuk A. (2013), Universities of the Third Age in Poland. Emerging Model for $21^{\text {st }}$ Century, "Journal of Education, Psychology and Social Sciences", 1.

Kresl P.K., Daniele I. (2010), The Aging Population and the Competitiveness of Cities. Benefits to the Urban Economy, Cheltenham: Edward Elgar.

Konieczna-Woźniak R. (2001), Uniwersytety Trzeciego Wieku w Polsce, Poznań: Wydawnictwo Eruditus.

Marcinkiewicz A. (2012), Uniwersytet Trzeciego Wieku jako instytucja przeciwdziałajaca marginalizacji osób starszych, „Ogrody Nauki i Sztuki”, 2.

McClusky H.Y. (1971), Education: Background Paper for 1971 White House Conference on Aging, Washington.

Obwieszczenie Marszałka Sejmu Rzeczypospolitej Polskiej z dnia 24 sierpnia 2015 r. w sprawie ogłoszenia jednolitego tekstu ustawy - Prawo o stowarzyszeniach (Dz.U. 2015, poz. 1393).

Obwieszczenie Marszałka Sejmu Rzeczypospolitej Polskiej z dnia 18 grudnia 2015 r. w sprawie ogłoszenia jednolitego tekstu ustawy o fundacjach (Dz.U. 2016, poz. 40).

Obwieszczenie Marszałka Sejmu Rzeczypospolitej Polskiej z dnia 1 lutego 2016 r. w sprawie ogłoszenia jednolitego tekstu ustawy o działalności pożytku publicznego i o wolontariacie (Dz.U. 2016, poz. 239).

Ogólnopolska Federacja Stowarzyszeń Uniwersytetów Trzeciego Wieku (2012), ZOOM na UTW. Zestawienie danych z badania ilościowego - wersja do konsultacji (stan na dzień 30 listopada 2012 r.), Warszawa.

Polsko-Amerykańska Fundacja Wolności, Uniwersytety Trzeciego Wieku (UTW), www.pafw.pl/programy/program/203\#.V3edXBLz_k4 (dostęp: 12.02.2016).

Schwarz D., Lentzy J., Hipp C. (2008), Senior Educational Programs for Compensating Future Student Decline in German Universities, [w:] F. Kohlbacher, C. Herstatt (eds.), The Silver Market Phenomenon. Business Opportunities in an Era of Demographic Change, Heidelberg: Springer.

Szluz B. (2009), Kreacyjne formy zagospodarowania czasu wolnego i aktywizowania osób starszych na przykładzie Uniwersytetu Trzeciego Wieku, [w:] J. Daszykowska, R. Pelczar (red.), Czas wolny: przeszłość, teraźniejszość, przyszłość, Stalowa Wola: Wydawnictwo Katolickiego Uniwersytetu Lubelskiego, WZNoS.

Uniwersytety trzeciego wieku 1975-2013, „Uniwersytety Trzeciego Wieku. Ogólnopolski Biuletyn UTW" 2013, 1.

Uniwersytety Trzeciego Wieku, Prof. dr med. Halina Szwarc-założycielka pierwszego UTW w Polsce, www.utw.pl/index.php?id=251 (dostęp: 12.02.2016).

Ustawa z dnia 6 kwietnia 1984 r. o fundacjach (Dz.U. 1991, nr 46, poz. 203).

Ustawa z dnia 7 kwietnia 1989 r. - Prawo o stowarzyszeniach (t.j. Dz.U. 1989, nr 20, poz. 104; Dz.U. 2015, poz. 1393, 1923).

Ustawa z dnia 24 kwietnia 2003 r. o działalności pożytku publicznego i o wolontariacie (t.j. Dz.U. 2003, nr 96, poz. 873; Dz.U. 2016, poz. 239).

Ustawa z dnia 27 lipca 2005 r. - Prawo o szkolnictwie wyższym (Dz.U. 2005, nr 164, poz. 1365). 
Ustawa z dnia 11 lipca 2014 r. o zmianie ustawy - Prawo o szkolnictwie wyższym oraz niektórych innych ustaw (Dz.U. 2014, poz. 1198).

Zan L. (1993), Die akademische Seniorenbildung. Eine historische Bilanz in methodisch-didaktischer Abricht, Weinheim: Deutscher Studien Verlag.

Ziębińska B. (2007), Uniwersytety Trzeciego Wieku jako instytucje przeciwdziałajace marginalizacji osób starszych, Katowice: Wydawnictwo Uniwersytetu Śląskiego.

\section{SUMMARY}

Main objective of this paper is to describe emergence of a Polish Universities of the Third Age model. Article indicates main organizational changes of these institutions conditioned by internal and external factors. The author describes differentiation factors and characteristics of these institutions for elderly.

Keywords: law; the Third Age Universities; silver economy; creative ageing policy; Lifelong Learning 